\title{
Reivindicación de una modernidad del sur. El reconocimiento del «género humano» en el pensamiento hispano del siglo XVI
}

por

\author{
Jorge Polo Blanco ${ }^{1}$
}

Escuela Superior Politécnica del Litoral (ESPOL), Ecuador

En el presente trabajo queremos esbozar una vindicación del pensamiento hispano que, al calor de la conquista de América, elaboró un potente cuerpo de reflexiones innovadoras que rompía con los moldes epistémicos e ideológicos del teocratismo medieval. Este pensamiento, puesto en marcha principalmente por figuras pertenecientes a la orden religiosa de los dominicos, se construyó dentro de los moldes teológicos de la escolástica pero, en realidad, abrió un terreno fecundo e intelectualmente inédito en lo jurídico, lo moral y lo antropológico-filosófico. Su contribución teórica, en ese sentido, fue de una envergadura extraordinaria, no siempre valorada por la historiografía. Y ese pensamiento, que constituyó un eslabón primigenio y primordial en la germinación de la modernidad, se produjo en un contexto sureño y católico. Es verdad que aquella incipiente modernidad quedó sepultada y obturada ya en el último cuarto del XVI y, principalmente, a partir del 1600. El testigo pasó entonces a los países protestantes del norte, como Holanda. Pero creemos imprescindible conocer y estudiar aquel pensamiento hispano que alumbró por vez primera la seminal categoría de "género humano», con todas las implicaciones que ello conllevaba.

Palabras Clave: conquista de América; Escuela de Salamanca; género humano; derecho de gentes.

Cómo citar este artículo / Citation: Polo Blanco, Jorge, "Reivindicación de una modernidad del sur. El reconocimiento del género humano en el pensamiento hispano del siglo XVI", Revista de Indias, LXXVIII/273 (Madrid, 2018): 361-397. https://doi.org/10.3989/ revindias.2018.011.

1 hiperbolik1983@hotmail.com, jorge.polob@ug.edu.ec, ORCID iD: https://orcid.org/ 0000-0001-9415-5406. de uso y distribución Creative Commons Reconocimiento 4.0 Internacional (CC BY 4.0). 


\section{LEYENDA NEGRA Y LEYENDA DORADA}

Resulta evidente, más allá de toda duda razonable, que los primeros lustros de la conquista y dominación española de las tierras de ultramar contuvieron episodios especialmente virulentos en lo que a la explotación de las poblaciones aborígenes se refiere. Pero también es cierto, y esto es precisamente lo que queremos mostrar en este trabajo, que casi desde el principio hubo un simultáneo cuestionamiento de dichas prácticas. «No habían pasado veinte años desde que Cristóbal Colón diera gracias a Dios por llevar su expedición a buen fin en tierras de América [...], cuando se alzó el primer clamor de justicia a favor de los indios. La conciencia española se vio atormentada por los acontecimientos de América tan pronto como se inició la conquista, pues se plantearon cuestiones complejas en cuanto llegaron a España los primeros indios [...]. No obstante, la primera protesta en América, que fue lo bastante severa y lo bastante poderosa para dejare oír a través del mar, en España, se produjo en 1511, cuando Fray Antonio de Montesinos atacó audazmente la conducta de los pobladores españoles» ${ }^{2}$. El inmortal Bartolomé de Las Casas estaba presente cuando aquel desconocido fraile dominico se subió al púlpito en una humilde iglesia de techo de paja sita en La Española, para pronunciar desde allí condenatorias palabras contra la maquinaria colonizadora. Bien es cierto que esos sermones, tal y como Las Casas los transcribe en su Historia de las Indias (esto es, más de cuarenta años después), pudieran ser en cierto modo una reconstrucción a posteriori repleta de interpolaciones, con el objeto de presentar una suerte de genealogía de temas polémicos netamente lascasianos $^{3}$. En cualquier caso, otras fuentes atestiguan que la intervención crítica de Montesinos sí se produjo, fuere cual fuese su intensidad concreta.

Aquel apasionado sermón, que escandalizó a colonos y encomenderos e incluso llegó hasta oídos de Fernando el Católico, supuso un hito en la historia de la humanidad. Desde poderosas instancias, claro está, se intentó acallar tan «dañina opinión». Pero, en cualquier caso, la voz había quedado alzada de manera inmarcesible. ¿Qué dijo el fraile Montesinos? Ante todo denunció, claro está, la «crueldad y tiranía» usada por los colonos, quedando éstos sumidos en pecado mortal por tan ignominiosa conducta. Pero, lejos de suponer una crítica meramente moral, ponía en cuestión la «legitimidad» y la «autoridad» de los españoles para declarar la guerra a aquellas gentes. Y esto era ya una cuestión de estado. Pero el asunto iba incluso más allá, pues Montesinos dejó dicho lo siguiente: «Estos, ¿no son hombres? ¿No tienen ánimas

2 Hanke, 1988: 29.

3 Losada, 1970: 62. 
racionales?» $\gg^{4}$ Y aquí el problema alcanzaba los máximos umbrales concebibles, toda vez que surgía la cuestión de la «humanidad» de las poblaciones originarias. Montesinos, que llegó a exponer la lista de agravios delante del mismísimo monarca, y del que sólo conocemos este sermón referido por otras fuentes (pues de él no nos ha llegado retrato o escrito alguno), puso sobre el tapete toda la complejidad teológica, moral, jurídica, política y filosófico-antropológica que el Mundus Novus abrió en la conciencia tardo-medieval y renacentista del Viejo Mundo. Y fueron los religiosos españoles los que abordaron, prácticamente desde el minuto uno de la Conquista americana, este nuevo horizonte que se abrió para transformarlo todo ${ }^{5}$.

No podemos dejar de considerar las nociones de «imperio generador e imperio depredador», distinguidas por el filósofo Gustavo Bueno. Los imperios generadores llegan a compartir muy extensamente sus instituciones lingüísticas, tecnológicas, económicas, artísticas o religiosas con las sociedades humanas intervenidas. Por el contrario, un imperio depredador sería aquél que restringe todos esos dispositivos culturales para uso exclusivo de los colonos. En ese sentido, y al hablar del imperio español, Bueno señala que «lo que tenemos por cierto es que su estructura no puede reducirse a la condición de "máquina depredadora" que tantos quieren atribuirle» ${ }^{6}$. Esa condición, en cambio, sí podría atribuirse al imperialismo desplegado por las potencias anglosajones y protestantes en América del Norte. Uno de los rasgos más evidentes de esa índole depredadora puede detectarse en el afán puritano de no mezclarse biológicamente con las poblaciones aborígenes; aspecto, como es de sobra conocido, que jamás se dio en el imperio católico español, pues en éste el mestizaje matrimonial era una práctica absolutamente normalizada. El mexicano José Vasconcelos, en La raza cósmica, señalaba cómo el colonizador inglés que ocupó las tierras norteamericanas se reproducía de una forma esencialmente endogámica. Los blancos que poblaron Norteamérica sólo se mezclaban con otros blancos, y el repudio casi físico que sentían con respecto a los pobladores originarios es algo que no se produjo de una manera análoga y equiparable en las colonias hispanas7. En ese sentido, la noción misma de «mestizo» habría resultado aberrante para un puritano del norte. Y, además, el mestizaje lingüístico fue potentísimo; muchísimos colonos españoles aprendieron lenguas indígenas y, a su vez, existió un prurito deliberado de enseñar la lengua castellana a los pobladores autóctonos. Todo ello fue

\footnotetext{
4 Hanke, 1988: 33.

5 Serna, 2012.

6 Bueno, 1999: 370.

7 Vasconcelos, 2001: 14.
} 
generando, desde el primer momento, una creciente unidad lingüística, jurídica, política y religiosa en los abigarrados e inmensos territorios de la América Hispana que no podía comprenderse como un mero proyecto de homogeneización economicista y depredadora. En un esquema semejante no habría encajado, por ejemplo, la prolija fundación de ciudades y universidades tal y como esto se produjo dentro del imperio español. Un ejemplo extremo de esta misma posición puede hallarse también en tierras americanas; véase la obra del historiador argentino Ricardo Levene, que en 1951 publicó un texto cuyo título era harto elocuente al respecto: Las Indias no eran colonias ${ }^{8}$.

Bien es verdad, no obstante, que tampoco podemos bascular hacia el otro extremo, esto es, hacia una lectura que se limita a señalar que los atropellos y abusos (verdaderas masacres, en muchas ocasiones) perpetrados por los colonos españoles forman parte de una suerte de «leyenda negra» anti-española construida secularmente por sus enemigos en el tablero geopolítico. Sin duda, hubo algo de todo ello9. Pero utilizar dicha leyenda para negar «todos» esos abusos resulta absurdo, entre otras cosas porque las cabezas pensantes más importantes del siglo XVI español abordaron dicha problemática con una intensidad indisimulada. Sin acercarnos lo más mínimo al insalubre chauvinismo, podemos decir con verosimilitud que muy probablemente ofrezca España un caso realmente inédito en la historia de las civilizaciones humanas, a saber, el de una nación imperial que revisa, a través de un verdadero examen de conciencia, su obra colonizadora en el preciso momento de empezar a desarrollarla. Sin ocultar, insistimos en ello, que los abusos terribles y los crímenes abyectos existieron. Porque tampoco debemos contribuir a la construcción de una suerte de «leyenda dorada» de la conquista hispanoamericana; leyenda que, por cierto, ya estaba presente en López de Gómara, cronista español del siglo XVI que sólo supo ver bendiciones y parabienes en la acción conquistadora de los españoles ${ }^{10}$.

Juan del Valle, primer obispo de Popayán, había ocupado la cátedra de Artes en Salamanca. Cuando llegó a las remotas tierras de la Nueva Granada pudo comprobar in situ la inoperancia de todas las cédulas reales que habían pretendido codificar y establecer un trato humanitario de los indios. Horrorizado por la brutalidad del sistema económico colonial, clamó contra la utilización de los moradores autóctonos como verdaderas bestias de carga que transportaban mercancías (oro, principalmente) de forma inhumana a través

\footnotetext{
8 Levene, 1991.

9 Vélez, 2014.

10 Gómez de Gómara, 1941.
} 
de angostas e inaccesibles rutas de una accidentadísima topografía ${ }^{11}$. "Tal era la situación de la población indígena en la parte visitada por el obispo, su protector, lo que proporciona una idea de la suerte del indio en la primitiva sociedad colonial [...]. La coacción era inherente al sistema mismo, pese a que su frecuencia, espectacularidad y la dosis de crueldad empleada, dependían en cada caso del carácter personal del respectivo encomendero o administrador. Ninguna cédula real fue capaz de alterar este estado de cosas, ni lo hubiera podido cambiar, salvo transformándose totalmente la estructura del sistema colonial» ${ }^{12}$. Recusado ante la Real Audiencia por los encomenderos, que no le perdonaban su «intromisión», Juan del Valle no cejó en su lucha protectora de los indios. Detestado por los colonos, su enfrentamiento con ellos era ya descarnado en 1555 .

Pero este notable caso nos sirve para comprobar la ambivalencia constitutiva de la colonización española, toda vez que desde el propio inicio de la Conquista hay evidentes tendencias (algunas de ellas muy cercanas a los propios centros de poder, como veremos a continuación) favorables al indio. Nuestro historiador, antes de narrarnos las hazañas del primer Obispo de Popayán (y a pesar de emitir juicios muy duros contra los encomenderos españoles) no puede dejar de reconocerlo: «Sobra decir que, dadas las circunstancias, la legislación indiana hace honor a España, si se la juzga abstractamente por el contenido humanitario de la mayoría de sus leyes. Asimismo causa sorpresa y aun admiración el deseo de comprensión que para el indio americano hubo por entonces en vastos círculos españoles» ${ }^{13}$. Ese reconocimiento es fundamental, porque verificamos que la intelectualidad española del momento siempre quiso y supo abordar, cuerpo a cuerpo, todo el compendio de acuciantes problemas teológicos, morales, jurídicos y políticos que la dura realidad de la Conquista iba planteando. Y ello no es óbice para constatar la existencia de múltiples matanzas y horrendos crímenes; porque es evidente que hubo una historia secular de expolio y explotación, qué duda cabe. Es más, puede localizarse en la Conquista de América nada menos que el movimiento histórico que puso en marcha los procesos de acumulación de riqueza que habrían de constituirse en los orígenes remotos de la sociedad capitalista ${ }^{14}$. Ésa es la doble faz de la Conquista española.

\footnotetext{
11 Friede, 1961: 83-84.

12 Ibidem: 91.

13 Ibidem: 17.

14 Marx y Engels, 1972: 37 y 60.
} 


\section{UN IMPERIO QUE, SIN DEJAR DE SERLO, HIZO COSAS EXTRAÑAS}

Las Leyes de Burgos de 1512, que pueden considerarse la primera cristalización jurídica derivada de la profunda crisis moral abierta en el corazón mismo del Imperio, fueron el efecto de esa gran conmoción civilizatoria que supuso el encuentro con las tierras y los pueblos americanos ${ }^{15}$. Conmoción para los europeos, calamidad para los nativos. Con dichas Leyes se establecía un primer código jurídico indiano sobre el funcionamiento de las encomiendas, y en él se recogían disposiciones para impedir el maltrato gratuito de los indios y su excesiva sobreexplotación. Es verdad, no obstante, que su condición misma de siervos subsistía en el texto. Esto es, aunque se trataba de dispensar un trato más benévolo y humanitario a los pobladores autóctonos, se daba por supuesta la legitimidad de la soberanía política de España. Se ponía en cuestión el dominio tiránico ejercido por muchos españoles, pero no se cuestionaba el dominio en sí.

Poco después, no obstante, un amplio conjunto de letrados, teólogos y canonistas estaban ya disputando y escribiendo tratados para empezar a considerar críticamente importantes aspectos de la conquista e incluso para cuestionar la legitimidad que tenía la Carona a la hora de ejercer pleno dominio sobre aquellas tierras; legitimidad que siempre remitía a las bulas papales de Alejandro VI otorgadas en 1493. ¿Acaso había pretendido el Sumo Pontífice otorgar a la corona española un título de plena autoridad y jurisdicción (y legítima posesión) de las nuevas tierras halladas, o se trataba de una mera misión evangelizadora y espiritual? La disputa pareció resolverse con la conclusión de que la donación papal había implicado la concesión a la Corona de España de un «justo título» sobre las nuevas tierras descubiertas y por descubrir, y no ya una mera misión evangelizadora. Muchos frailes dominicos, en cambio, no desistieron en su empeño por impugnar de raíz semejante concepción.

No debe olvidarse la figura de Vasco de Quiroga, que desde México escribió sobre la natural mansedumbre y bondad de los indios y contra la espeluznante forma en que eran tratados por los españoles, como si fueran esclavos o bestias. Bien es cierto que el obispo Quiroga, aun reconociendo el potencial espiritual y racional de los autóctonos, pensaba y escribía desde las coordenadas de un humanismo utopista de corte paternalista que, en muchas ocasiones, lanzaba sobre el indio una mirada condescendiente; algo que lo alejaba del radicalismo lascasiano ${ }^{16}$. En cualquier caso, esta tensión dentro de

15 Ramos et al., 1984.

16 Serrano Gassent, 2001. 
la conciencia hispana persistió hasta alcanzar su punto álgido en 1550, momento en el que se produce la histórica junta de Valladolid. Con la disputa que entonces mantuvieron Bartolomé de las Casa y Juan Ginés de Sepúlveda (y, con ellos, todos sus respectivos partidarios) tuvo lugar la confrontación absoluta de dos visiones distintas de la legitimidad de la conquista de América que, a la postre, remitía al enfrentamiento de dos visiones antropológico-filosóficas y jurídico-políticas irreconciliablemente antagónicas. Con el añadido esencial de que dicha disputa, lejos de ser un asunto ventilado en los claustros de cátedras o monasterios, adquirió hechuras de «cuestión de Estado». Fue la propia Corona, hemos de tenerlo presente, la que promovió y posibilitó este memorable acontecimiento.

Las Casas, que había ingresado en la orden dominica en 1523, regresó por última vez de América en 1547, a la edad de 73 años, tras medio siglo de estancia y andanzas por tierras americanas. Pero desde mucho antes había venido ejerciendo su labor de incansable denuncia contra el maltrato que sufrían los indios a mano de los españoles; lo hizo en la Nueva España, pero también en la metrópoli, como en aquel regreso intempestivo de 1515 que llevó a cabo con la intención de promulgar en la Corte su furibunda campaña indiana. En 1543, por ejemplo, presentó junto a fray Rodrigo de Andrada una vehemente relación al Consejo de Indias, detallando la crueldad del comportamiento colonial. Su conciencia de tan eminente problema, sin embargo, data de una fecha tan temprana como 1514. Antes de esa fecha, el propio Las Casas poseyó encomiendas e indios que trabajaban bajo su potestad ${ }^{17}$. Pero, como decíamos, renunció a todo ello para dedicar su vida entera a la defensa indesmayable de la dignidad de los indios. Se enfrentó a todos aquéllos que aseveraban que los pobladores aborígenes apenas eran capaces de razonar, como había declarado Pedro de Betanzos ante el consejo de Indias, a finales de 1532 o principios de 1533. Pero el Obispo de Chiapa, pues en aquellas tierras ejerció su magisterio, condujo su labor hasta el corazón mismo del Imperio, escribiendo y disertando en Valladolid y Sevilla. Influyendo, además, en los círculos más estrechamente ligados a las altas esferas del poder ${ }^{18}$.

Hemos de comprender, por lo tanto, que todas las discusiones teóricas albergaban dentro de sí una carga explosiva en un nivel eminentemente práctico. Porque si los indios eran considerados criaturas racionales, resultaba entonces muy complejo justificar su expolio indiscriminado; por el contrario, si eran considerados bestias desalmadas e infrahumanas, tal vez la guerra de conquista contra ellos estaba del todo justificada. Por no hablar del simple

17 Hanke, 1988: 32.

18 Lavallé, 2009. 
sintagma «derechos de los indios», que de adquirir visos de verosimilitud lo transformaría absolutamente todo. Lo teológico y lo filosófico, lo jurídico y lo moral, todos esos elementos aparecían inextricablemente vinculados y albergaban una evidente implicación política. Porque todo ese aparato discursivo se estaba construyendo y entretejiendo a la par que se desarrollaba la conquista. «El rey dio el paso final y ordenó el 16 de Abril de 1550 que todas las conquistas deberían suspenderse en el Nuevo Mundo hasta que un grupo especial de teólogos y consejeros decidiera acerca del método más justo para realizarlas. Las Casas había obtenido su primer triunfo; la maquinaria de la conquista se detuvo en seco [...]. Probablemente nunca antes, ni después, un poderoso emperador - $\mathrm{y}$ en 1550 Carlos $\mathrm{V}$, el sacro emperador romano, era el gobernador más poderoso en Europa, además de poseer un gran imperio en ultramar-, había ordenado que se detuvieran sus conquistas mientras se decidía si eran o no justas» ${ }^{19}$. Hemos arribado al asunto más decisivo.

Decir que la «maquinaria de la conquista se detuvo en seco», como hace Lewis Hanke, puede resultar hiperbólico; pero no deja de ser un hecho histórico sin parangón que un todopoderoso monarca decida someter una cuestión de estado, la más importante de todas, a la deliberación de la inteligencia teológica, moral y jurídica. «Los monarcas españoles llegaron al extremo de tolerar la discusión en público de cuestiones tan peligrosas como la de si eran justas las guerras contra los indios y si España tenía un justo título sobre las Indias $\gg{ }^{20}$. No creemos que pueda decirse que otras potencias colonialistas hicieron algo análogo o equiparable. En ese sentido, resulta muy digno de mención el hecho de que Las Casas, el más activo y mordaz de los críticos de la Conquista española, jamás tuviera problemas para imprimir y distribuir sus escritos, algunos de los cuales eran ciertamente provocadores y manifiestamente contrarios a la lógica del poder vigente; mientras que sus enemigos teóricos, fieles defensores de la política imperial, encontraran muchas más dificultades para imprimir sus escritos. Algunos textos de Sepúlveda y Fernández de Oviedo, de hecho, no vieron la luz hasta el siglo XIX ${ }^{21}$. Bien es cierto, no obstante, que tras la Disputa de Valladolid el que tuvo serias complicaciones para publicar sus tratados fue Las Casas; de hecho, publicó algunos de ellos de manera subrepticia y sin autorización legal, en 1552 y 1553. Mientras que el Epistolario de Sepúlveda, en el cual se recogen y plasman los argumentos que éste desplegó en la mencionada controversia, sí fue publicado de forma autorizada en 1557 .

\footnotetext{
19 Hanke, 1985: 93.

20 Hanke, 1988: 78.

21 Ibidem: 84.
} 


\section{El epicentro Salmantino. Hacia un RECONOCIMIENTo DEL GÉNERo HUMANO}

Fernán Pérez de Oliva, maestro de la Universidad de Salamanca y escritor humanista, comprendió que un nuevo concepto de hombre se estaba abriendo paso a raíz del maravilloso encuentro con otros pueblos ignotos. El mundo quedaba aunado ya en una historia común y una misma dignidad había de ser reconocida para todos los hombres ${ }^{22}$. También el pensamiento de Francisco de Vitoria, como el de todos los grandes pensadores de su tiempo, resultaría ininteligible sin la experiencia decisiva de América. Él jamás puso pie en aquellas tierras, pero el convento de San Esteban en Salamanca fue un punto neurálgico esencial en la emisión y recepción de todo tipo de documentos e informes vinculados a los asuntos indianos. Y en esa decisiva confrontación con lo que estaba acaeciendo al otro lado del Atlántico la doctrina tenía que tomar tierra. De aquel convento, además, salieron los primeros dominicos que habrían de jugar un papel tan esencial en el discurrir espiritual de Hispanoamérica.

En su Relectio de potestate civil, leída en 1528, podemos encontrar una aproximación explícita a la sanción popular del poder político constituido, alejándose de toda concepción puramente teocrática y providencialista del mismo. Pero, sin duda, su concepción más grandiosa habría de ser aquélla que pensara una humanidad vinculada por un mismo cuerpo moral; aspecto que, a la poste, derivó hacia el entendimiento de un derecho natural universal al que estaban sujetos todos los estados de la tierra. Esta primera y decisiva piedra en la construcción de un auténtico derecho internacional no podía desvincularse de los principios eminentemente cristianos en los que siempre se movió Vitoria, eso es indudable, pero en realidad él ya pudo comprender que ese derecho «obligaba» a toda la comunidad de estados, incluidos los no cristianos. «Y es que el orbe todo, que en cierta manera forma una república, tiene poder de dar leyes justas y a todos convenientes, como son las del derecho de gentes [...]. Y ninguna nación puede darse por no obligada ante el derecho de gentes, porque está dado por la autoridad de todo el orbe» ${ }^{23}$. La igualdad natural de hombres y razas, que devenía en igualdad jurídica de pueblos y estados, es lo que está detrás de esa concepción del totus orbis puesta en juego por Vitoria. Y tales tesis quedaban dichas, sostenidas y defendidas en el siglo XVI. Anticipando seminalmente nociones de derecho internacional, Vitoria osó equiparar, en lo que a la sujeción a un mismo de-

\footnotetext{
22 Poncela González, 2015: 62-77.

23 Vitoria, 1985: 19.
} 
recho universal de gentes se refiere, el imperio de Carlos V y los imperios de Atahualpa y Moctezuma24.

Y para calibrar en su justa medida el alcance de semejantes conceptos hemos de hacer mucho hincapié en el hecho de que tales cosas se estaban diciendo en 1528, ni más ni menos. Esto es, en un mundo en el que la cristiandad occidental se hallaba en permanente guerra con los turcos y, en general, con el universo sarraceno. En esas condiciones históricas resultaba una entelequia imaginar siquiera la existencia de algo parecido a una comunidad internacional de pueblos libres e iguales entendida como la expresión de una misma república universal. El «descubrimiento» de América, el encuentro con gentes que jamás habían vivido bajo la égida cristiana, habría de removerlo todo a nivel teológico, moral y jurídico-político. Francisco de Vitoria, gran admirador de Erasmo, quizás no fue un espíritu crítico tan incendiario y cáustico como habría de serlo Las Casas; pero su importancia, así debe reconocerse, es decisiva e imperecedera. Es verdad que Vitoria nunca estuvo en América, como ya señalamos, ni participó en las numerosas juntas indianas convocadas por el Rey; pero numerosos discípulos llevaron sus enseñanzas por toda la geografía de las indias americanas y hasta las Filipinas ${ }^{25}$.

Cuando Vitoria llegó a España desde París, en 1523, ya traía consigo una inquietud indiana. En la universidad parisina había tenido conocimiento de las reflexiones del escocés John Mair (o John Major), con el cual habría de tener enormes diferencias, precisamente porque éste admitía la licitud de una ocupación bélica como primer e imprescindible paso para llevar a cabo el proyecto evangelizador, como señalaba en sus Comentarios al Libro II de las Sentencias de Pedro Lombardo (1510). En su memorable Relectio de Indis, leída en enero de 1539, Vitoria aborda no la defensa humanitaria del nativo americano, su reivindicación como hombre, sino la cuestión crucial de la «legitimidad» del dominio español en el Nuevo Mundo. Para ello debía enfrentarse a la influyente y poderosa teoría del poder político que provenía de Enrique de Susa, más conocido por el Ostiense, canonista del siglo XIII. Según esta concepción, todos los poderes espirituales y temporales fueron otorgados por el Redentor a San Pedro, el primer papa, el cual a su vez los transmitió plenamente a todos sus sucesores. Estas ideas todavía estaban vigentes en el siglo XVI, por ejemplo en Palacios Rubios, uno de los más influyentes consejeros de Fernando el Católico. Era éste, quizás, el último rescoldo vivo de aquel agustinismo político medieval que había supeditado el orden natural al orden sobrenatural.

\footnotetext{
24 Rodríguez Molinero, 1991: 43-75.

25 Hanke, 1988: 402.
} 
Vitoria arremetió explícita y contundentemente contra estas teorías. «El Papa no es señor civil o temporal de todo el orbe, hablando de dominio y potestad civil en sentido propio» ${ }^{26}$. Ni siquiera Cristo tuvo tal poder temporal, por lo tanto mucho menos habría de tenerlo el Papa. El Sumo Pontífice, en todo caso, alberga una suprema autoridad «sólo» con respecto a los fieles cristianos, pero jamás sobre los no cristianos. El Papa, por todo ello, no es la fuente del poder político; y, en razón de ello, tampoco puede otorgar bula para ejercer ninguna política de dominio imperial. Pero tampoco el Emperador es el señor de todo el orbe, añade. Es más, advierte Vitoria que aun dándose el caso de que el Emperador fuese señor de todo el mundo ello no le facultaría en ningún caso para adueñarse de las tierras americanas, despojando a los naturales de sus posesiones. Incluso afirmará que aquellos hombres no están obligados a someterse a la fe cristiana ni supone esto motivo suficiente para hacerles la guerra. En De temperantia, las relecciones de 1537, llegó a proponer de forma más o menos velada una reamericanización de América; incluso pudo comentar que las repúblicas indias no eran parte de España, en sentido estricto. Restituir América a sí misma, en definitiva, era lo que se traslucía en semejantes disquisiciones. Vitoria, de tal modo, habría formulado tesis abiertamente indigenistas algunos años antes de la Controversia de Valladolid. Bien es verdad que dos años después, en 1539, y ante la consulta del emperador Carlos V, modera su posicionamiento y señala que no sería conveniente que el Rey de España abandonara «por completo» la administración de aquellas tierras ${ }^{27}$.

En Relectio de Indis, por lo tanto, se pregunta en primer lugar si los indios, antes de la llegada de los españoles, eran los legítimos y verdaderos dueños de sus posesiones. Y toda la argumentación de Vitoria camina hacia una respuesta afirmativa a semejante cuestión. «Queda, pues, firme de todo lo dicho, que los bárbaros eran, sin duda alguna, verdaderos dueños pública y privadamente, de igual modo que los cristianos, y que tampoco por este título pudieron ser despojados de sus posesiones como si no fueran verdaderos dueños, tanto sus príncipes como las personas particulares» ${ }^{28}$. Pero no hemos de olvidar que esta disposición, que resalta la «ilegitimidad» de una conquista materializada a través del despojo de todas las posesiones de los naturales americanos, va estrechamente vinculada a una concepción del género humano igualitaria. «Porque en realidad no son dementes, sino que a su modo ejercen el uso de la razón. Ello es manifiesto, porque tienen establecidas sus cosas

\footnotetext{
26 Vitoria, 1985: 44.

27 Dumont, 2009: 87-91.

28 Vitoria, 1985: 36.
} 
con cierto orden. Tienen, en efecto, ciudades, que requieren orden, y tienen instituidos matrimonios, magistrados, señores, leyes, artesanos, mercados, todo lo cual requiere el uso de razón [...]. Por lo que creo que el que nos parezcan tan idiotas y romos proviene en su mayor parte de la mala y bárbara educación, pues tampoco entre nosotros escasean rústicos poco desemejantes de los animales» ${ }^{29}$. Indudablemente, podemos hallar en las valoraciones de Vitoria un implícito paternalismo que de algún modo prejuzga el «atraso cultural» de aquellas civilizaciones. En ese sentido, bien pudiera ser que ese reconocimiento de la dignidad del «otro» no terminase de aceptar su alteridad intrínsecamente valiosa y, por el contrario, sólo tratase de construir una forma blanda y suave de asimilación cultural ${ }^{30}$. Pero, a pesar de ello, no es menos cierto que hay en Vitoria un explícito y sincero reconocimiento de la humanidad de los indios, que albergan dentro de sí la misma capacidad de razón que hallamos en los cristianos. Destierra, por lo tanto, toda noción de inferioridad natural de aquellas gentes, e incluso entiende que en las instituciones de esas sociedades pueden hallarse indubitables huellas de recta racionalidad.

Por lo tanto, Vitoria se opondrá con todas sus fuerzas a todas esas concepciones que postulan las nociones de servi a natura o gens nata ad servitutem. Estas expresiones, «siervos por naturaleza» y «pueblos nacidos para la esclavitud», aparecerían en las tremendas argumentaciones que unos años más tarde emplearía Juan Ginés de Sepúlveda para defender, en la celebérrima Disputa de Valladolid, la legitimidad de la guerra española contra los indios. Y, por supuesto, Vitoria no dudará en arremeter contra todos aquéllos que hubieran osado invocar alguna suerte de mandato divino que otorgase a los españoles una licencia trascendente para perpetrar una masacre tras otra ${ }^{31}$.

Fray Vitoria anhelaba mostrar que no son causa justa de guerra los deseos por parte de un estado de ensanchar su propio territorio o el simple anhelo de gloria por parte del príncipe gobernante. Pero había algo que era todavía más contundente, toda vez que quedaba afirmado en el siglo XVI. «La diversidad de religión no es causa justa para una guerra» ${ }^{32}$. Locura sería, a su parecer, considerar que los naturales americanos eran infieles en el mismo sentido en el que lo eran los turcos, por ejemplo, toda vez que aquellas gentes jamás habían cometido injuria u ofensa alguna contra la religión cristiana, a la que ni siquiera conocían. Y, en cualquiera de los casos, la conversión había de ser un acto plenamente libre y consciente que jamás debía ser impuesto por la

\footnotetext{
29 Ibidem: 35.

30 Todorov, 1987.

31 Vitoria, 1985: 57.

32 Ibidem: 81.
} 
fuerza o el terror. «Por otra parte, la guerra no es argumento en favor de la verdad de la fe cristiana; luego por las armas los bárbaros no pueden ser movidos a creer, sino a fingir que creen y que abrazan la fe cristiana, lo cual es abominable y sacrílego ${ }^{33}$. Esto último reaparecería con extrema viveza en el tratado De unico vocationis modo omnium gentium ad veram religionem, de Bartolomé de las Casas ${ }^{34}$. Este método evangelizador, desarmado y pacifista, fue puesto en práctica en la década de 1540, en un territorio de la actual Guatemala que fue bautizado como Vera Paz. Y en un principio los frailes dominicos, imbuidos de principios lascasianos, lograron evangelizar a los nativos de dicha región sin emplear la fuerza punitiva. Sin embargo, a partir de 1555 el panorama cambia por completo, siendo el caso que muchos religiosos y catecúmenos son atacados y asesinados. Estos hechos, que hubieran supuesto un demoledor contraargumento fáctico a las tesis de Las Casas, se produjeron con posterioridad a la contienda de Valladolid.

Pero Fray Bartolomé siempre perseveró en la idea de que ni siquiera un rechazo por parte de los indios de la doctrina cristiana, cuando ésta ha sido bien enseñada, es condición suficiente para hacerles la guerra. «Aunque la fe haya sido anunciada a los bárbaros de un modo probable y suficiente y éstos no la hayan querido recibir, no es lícito, por esta razón, hacerles la guerra ni despojarlos de sus bienes» ${ }^{35}$. Vitoria estaba diciendo, ni más ni menos, que los pueblos de la tierra tenían pleno derecho a no ser cristianos, «incluso» cuando dicha fe les era expuesta y explicada por medios pacíficos; tales pueblos no podían ser atacados, mientras ellos a su vez no atacaran al mundo cristiano. Y como bien señaló Beltrán de Heredia en su imprescindible estudio, Vitoria «se opuso a identificar pura y simplemente a la cristiandad con la humanidad, y más todavía, a ver en ésta un mero objeto de dominación de iure por parte de aquélla» ${ }^{36}$. Produciendo una sacudida sin retorno en la médula de la cristiandad medieval, Vitoria entiende que todos los pueblos de la tierra, sean cristianos o no, quedan amparados por un mismo derecho natural. Hay un derecho común al género humano; ésa era la noción esencial puesta en juego. La fecundidad de este universalismo jurídico, basado en una noción de totus orbis que comprende la comunidad de todos los pueblos y la fraternidad de todos los hombres, se dejará notar muy vivamente en toda la escuela española del derecho de gentes de los siglos XVI y XVII; mereciendo una mención especial, indudablemente, el De Legibus de Francisco Suarez.

\footnotetext{
33 Ibidem: 54.

34 Casas, 1975.

35 Vitoria, 1985: 54.

36 Beltrán de Heredia, 1967: CXLVI.
} 
Es cierto que Vitoria también plantea la existencia de un título de justa intervención bélica, si bien es verdad que bajo muy escasos supuestos; son éstos la antropofagia y los sacrificios humanos. Semejantes tiranías vulneran los principios más básicos del derecho de gentes, y puede usarse legítimamente la coacción violenta para obligar a los aborígenes a detener tales prácticas ${ }^{37}$. Pero mucho cuidado, porque dicha intervención humanitaria debe limitarse a propiciar la defensa de las víctimas, y nada más; ni siquiera aquellos reinos, ciudades o imperios que cometan tales aberraciones deben por ello ser saqueados y despojados de sus posesiones. Y, matiza aún más Vitoria, las idolatrías que no causan víctimas humanas o las que se basan en costumbres sexuales diferentes a las que prevalecen en el mundo cristiano, jamás podrán constituir motivo de guerra justa ${ }^{38}$.

Quizás uno de los documentos más impresionantes de Vitoria es la carta a su compañero de orden, Miguel Arcos, fechada en 1534. Allí, con tono amargo, Vitoria no comprende el proceder mezquino de los españoles en el Perú, la ilegitimidad de aquella guerra de conquista, la muerte torticera del prisionero Atahualpa y el sometimiento cruento y el expolio injusto de aquellas gentes que, hombres como nosotros, no deberían ser atropelladas de esa manera bajo ningún concepto. Conviene recordar que entonces Vitoria era el teólogo que regentaba la principal cátedra de la Universidad más importante del Reino. Es preciso señalar que la base de esa condena era la violación de un derecho de «humanidad» ${ }^{39}$. El teólogo dominico escribió y pronunció palabras duras, qué duda cabe. La teocracia pontificia y la legitimidad del imperio hispano quedaban cuestionadas desde sus cimientos. "Vitoria ha desmontado el viejo sistema teocrático descendente, en el que todo el poder deriva de Dios, así como la mentalidad de cruzada, especialmente viva entre los españoles en su lucha contra el islam y el judaísmo [...]. Sin embargo la principal innovación procede de un desplazamiento consistente en pensar la naturaleza del poder y del dominio no tanto a partir del derecho divino cuanto en términos de género humano, en términos de una igualdad natural y común a todos los hombres [...]. La categoría de "género humano" permitía sentar las bases mismas de un derecho de humanidad más allá de la diferenciación entre fieles e infieles, cristianos y gentiles, permitía, en fin, romper con la división establecida por Aristóteles entre hombres libres y esclavos por naturaleza ${ }^{40}$. Ésa fue la gran conmoción que tuvo a Salamanca como epicen-

37 Vitoria, 1985: 69.

38 Ibidem: 56.

39 Álvarez Uría, 2015: 145.

40 Ibidem: 156. 
tro. Y para poder entender en su justo término el potencial contenido en dichos escritos, no hemos de olvidar que Sixto V, en 1590, quiso incluir las Relecciones de Vitoria en el Índice de libros prohibidos. Pero las tesis del maestro salmantino se irían abriendo paso de manera incontenible, generando un cuerpo de discípulos inmediatos y mediatos de primer orden, dejándose sentir su influencia desde México hasta Lima.

Otro insigne teólogo de Salamanca, Domingo de Soto, había pronunciado en 1535 su propia «relección» acerca del controvertido y decisivo tema de la legitimidad de la Conquista. Llevaba por título De dominio, y afirmaba allí que el derecho es igual para todos los hombres, puesto que todos son de la misma naturaleza y nadie puede ser considerado siervo de otro. Soto albergaba profundas dudas acerca de la legitimidad del dominio imperial ultramari$\mathrm{no}^{41}$. Y, al igual que haría Vitoria cuatro años después, ponía en cuestión nada menos que las tesis teocráticas medievales, arguyendo que ni el Papa era dueño de todo el orbe (no podía otorgar lo que no era suyo, y eso convertía en papel mojado las bulas alejandrinas) ni el emperador tenía dominio sobre todas las tierras conocidas. Y, por otra parte, la fe y el bautismo no podían imponerse legítimamente mediante la coacción y el amedrentamiento ${ }^{42}$. Bien es verdad que Bartolomé de Carranza llevaría más lejos que Soto y que su maestro Vitoria las tesis que impugnaban el derecho de los españoles a ejercer un dominio político sobre los pueblos naturales de América ${ }^{43}$. Años después, por cierto, Carranza fue apresado por la Inquisición, dando lugar a un complejo y memorable proceso que se prolongaría durante años.

Diego de Covarrubias, otro maestro de Salamanca, también estableció como verdad apodíctica que todos los hombres son naturalmente libres. «La libertad es de derecho natural, y todos los hombres nacen libres por derecho natural» ${ }^{44}$. En su De iustitia belli adversus indos (1547-1548), comprendió que no es de justicia declarar la guerra a los indios simplemente porque sus estados no están organizados todo lo bien que podría estarlo desde un punto de vista civil y político. Y aunque sí haya justicia en la intervención destinada a evitar la muerte de inocentes que son sacrificados e inmolados en abyectos rituales, por supuesto, la idolatría en general tampoco es motivo de justa guerra. «No se puede declarar la guerra a los indios por el hecho de que sean infieles, y no profesan la fe de Cristo» ${ }^{45}$. No pueden aquellos pueblos ser

\footnotetext{
41 Soto, 1995.

42 Brufau Prats, 1988: 115.

43 Carranza, 1956: 38-57.

44 Covarrubias y Leyva, 1956: 185.

45 Idem.
} 
obligados a convertirse, aunque tengan noticia del Evangelio. «Por este motivo, no pueden ser obligados a admitir el imperio de los cristianos con el fin de que sea más fácil la conversión» ${ }^{46}$. Covarrubias, en la línea de todos los grandes teólogos y juristas salmantinos, afianza la jerarquía de las leyes, comprendiendo que la ley natural es superior a cualquiera de las leyes humanas y se muestra siempre inderogable frente a éstas. Ni siquiera la voluntad de un soberano puede quebrar la validez intrínseca e inmutable de esa ley natural ${ }^{47}$.

Hemos de apuntar (y no es ésta una cuestión menor) que ese "género humano» descubierto o reconocido por el pensamiento hispano del siglo XVI no podía desligarse de sus raíces eminentemente cristianas. En ese sentido, siempre podrá acusarse a dicho pensamiento de permanecer anclado en un molde irremediablemente eurocéntrico y, por consiguiente, de seguir reproduciendo y afianzando una lógica colonial que construía al «otro» como inferior y como subalterno ${ }^{48}$. Sólo con las «filosofías de la liberación» y las nuevas perspectivas «latinoamericanistas» emergidas en el siglo XX hallaremos en suelo hispanoamericano (o, siendo más precisos, iberoamericano y caribeño) un pensamiento que tenga por objeto situarse en una genuina exterioridad con respecto a esa lógica cultural eurocéntrica y neocolonial ${ }^{49}$. Todos los estudios que un Aníbal Quijano o una Rivera Cusicanqui realizaran sobre la pervivencia contemporánea de la «colonialidad del poder» y sobre la existencia de «estructura coloniales de larga duración» resultan absolutamente imprescindibles $^{50}$. Somos plena y analíticamente conscientes de ello, desde luego ${ }^{51}$. Y, a su vez, tampoco podemos dejar de recordar Ariel, la obra del uruguayo José Enrique Rodó, en la cual había quedado patente la conciencia de la influencia culturalmente nefasta que un «Norte Anglosajón» esencialmente pragmático y utilitarista podría llegar a ejercer sobre la textura social y espiritual de la América Hispana ${ }^{52}$. Y lo decimos porque creemos que sí debe notarse la diferencia e incluso la pugna entre dos espíritus heterogéneos que respondían, en realidad, a «dos modernizaciones diversas». Enrique Dussel, uno de los más fervientes críticos de ese canon cultural eurocéntrico que se articuló en torno a la Conquista de América, reconoció sin embargo la existencia de una

46 Ibidem: 187.

47 Covarrubias y Leyva, 1957.

48 Mignolo, 2003. Wallerstein, 2007.

49 Ardiles et al., 1973. Zea, 1974. Kusch, 1978. Dussel, 1985. Scannone, 1990. Salazar Bondy, 1995.

50 Quijano, 1992; 1997. Rivera Cusicanqui, 2010.

51 Polo Blanco, 2016

52 Rodó, 2007. 
«primera modernidad» (hispánica) que sí fue capaz de movilizar una reflexión profunda que cuestionaba de forma severa y autocrítica la «legitimidad» misma del proceso de colonización. Sin embargo, apunta Dussel, en la «segunda modernidad» (aquélla que se precipitó cuando España entró en decadencia y el eje del sistema-mundo colonial se desplazó hacia nuevos «centros» como Londres o Ámsterdam, desde el siglo XVII en adelante) dicha consciencia crítica desaparece por completo; la cuestión de la legitimidad de la Conquista ya ni siquiera emergerá como un «problema», y el sistema colonial quedará plenamente asimilado (naturalizado) en la conciencia biempensante de los europeos ${ }^{53}$. Sólo la primera «modernidad hispánica»se planteó críticamente, desde la reflexión teológica, filosófica y moral, lo que se estaba haciendo en las tierras de ultramar.

En cualquier caso, esa «modernidad del sur» a la que hacemos referencia en el título de este ensayo no deja de ser, es cierto, una modernidad «del sur de Europa». Pero, aun reconociendo esto último, no podrá obviarse el innegable potencial emancipador y liberador que se albergaba en el pensamiento y en la acción de muchos de aquellos teólogos españoles. Podemos escuchar, en ese sentido, las siguientes palabras: «El Virreinato aparece menos culpable que la República. Al Virreinato le corresponde, originalmente, toda la responsabilidad de la miseria y la depresión de los indios. Pero, en ese tiempo inquisitorial, una gran voz cristiana, la de fray Bartolomé de las Casas, defendió vibrantemente a los indios contra los métodos brutales de los colonizadores. No ha habido en la República un defensor tan eficaz y tan porfiado de la raza aborigen $»^{54}$. Fueron escritas nada menos que por José Carlos Mariátegui, el gran teórico socialista e indigenista peruano. Y otro autor tan poco sospechoso de ejercer prácticas teóricas eurocéntricas como Rodolfo Stavenhagen señaló que los despojos de tierras colectivas indígenas y las expediciones punitivas con el objeto de perpetrar masacres y exterminios fueron, en muchísimas ocasiones, más intensos y violentas «después» de la independencia política que durante el dominio español, pues una serie de legislaciones tutelares de la Corona garantizaban el control relativamente autónomo de sus tierras a estas comunidades ${ }^{55}$; un aspecto (el de conservar alguna potestad sobre las propias tierras) que tenía que ver con las formas jurídicas medievales propias del derecho hispano, el cual concedía algunos niveles de autonomía político-administrativa a ciertas entidades dentro del estado ${ }^{56}$.

\footnotetext{
53 Dussel, 1999: 156-158.

54 Mariátegui, 1956: 44.

55 Stavenhagen, 1988: 23.

56 Zavala, 1971, cap. VI.
} 
Y tampoco debe olvidarse que el desprecio hacia el indígena fue infinitamente más acusado y visceral en todos aquellos intelectuales decimonónicos que, imbuidos de positivismo europeo y pragmatismo norteamericano, odiaban con la misma virulencia la herencia indígena precolombina y la herencia española. Faustino Sarmiento y Juan Bautista Alberdi en Argentina, José Victorino Lastarria en Chile, José María Luis Mora y Francisco Pimentel en México, Mariano Cornejo y Javier Prado en Perú o Nicomedes Antelo en Bolivia, todos estos intelectuales, consideraban que el único modo a través del cual las jóvenes Repúblicas hispanoamericanas podían subirse al tren de la «modernización»y el «progreso» consistía en una «renuncia» al propio pasado: desasirse, en un ejercicio histórico de automutilación, de la herencia cultural hispana (porque entendían que los modelos a seguir, para alcanzar un verdadero desarrollo, venían del mundo anglosajón o, en todo caso, del francés) y, ante todo, eliminar el «elemento indígena» (por las vías expeditivas del ostracismo, la exclusión, el darwinismo social o, en todo caso, la asimilación); porque, además, la principal acusación que vertían contra la herencia hispana tenía que ver con el hecho (para ellos aberrante e intolerable) de que los españoles se habían mezclado con las razas viles e inferiores, esto es, con los pueblos indígenas ${ }^{57}$.

\section{UNA DISPUTA DE ALTOS VUELOS EN EL CORAZÓN DEL PODER Y EL ENFRENTAMIENTO DE DOS VISIONES DEL HOMBRE}

Es cierto que los miembros de la Orden de Predicadores fueron especialmente insignes en sus reflexiones y luchas en defensa de los indios; pero, sin duda alguna, el más combativo de los frailes dominicos fue el inmortal Bartolomé de las Casas. Cuando vino a España en 1539 trabajó incansablemente para tratar de influir en la Corona y en el Consejo de Indias, alertando de las prácticas abominables llevadas a cabo por muchos españoles, que humillaban la humanidad de los indios. En esos años escribió dos tratados, uno de los cuales habría de ser su celebérrima Brevísima relación de la destrucción de las Indias (que, no obstante, aparecería más tarde) ${ }^{58}$. Esta labor infatigable tuvo mucha influencia en la promulgación de las Leyes Nuevas de 1542, verdaderas ordenanzas reales a favor de los indios que, por ello mismo, perjudicaban directamente los intereses de los encomenderos españoles. Y más allá de su incidencia práctica parcialmente fallida, se ha de reconocer que dichas

\footnotetext{
57 Stavenhagen, 1988: 33-40.

58 Casas, 1982.
} 
leyes supondrían un antes y un después en el pensamiento político y jurídico occidental, como bien señala Fernando Álvarez-Uría, toda vez que con ellas se quebrantaba la tradición romana de conquista, expolio y abastecimiento de esclavos. Esa lógica avasalladora y depredadora aparece cuestionada casi desde el primer momento ${ }^{59}$.

En 1544 Las Casas fue nombrado en Sevilla Obispo de Chiapas y, cuando llegó a su puesto en 1545, se vio envuelto de lleno en la contienda beligerante con los conquistadores. En 1547 regresa a España y descubre con indecible inquietud que Juan Ginés de Sepúlveda, erudito y humanista muy bien relacionado en el arzobispado de Sevilla y en el Consejo de Indias, había terminado de componer un tratado para demostrar la licitud de la guerra contra los indios. Desde posiciones diametralmente opuestas a Las Casas, defenderá la existencia de las encomiendas a perpetuidad. Su tratado Democrates alter, sive de justis belli causis apud Indos (que estaba ya terminado en 1545) circulaba por la corte y, de hecho, se estaba dirimiendo si se autorizaba o no su impresión. Esta obra suponía un ataque polémico a todo el sistema levantado por los teólogos dominicos, los cuales habrían cometido la imprudencia de negar la legitimidad de los príncipes cristianos para someter aquellas paganas tierras. Cuando ese tratado, o un compendio del mismo, vino a parar a las manos de Las Casas éste se percató rápidamente del tremendo veneno que contenía. Y así se lo comunicó sin ambages al príncipe Felipe, futuro Felipe II. «Pues, si tantas leyes promulgadas, tantos decretos, tantas severas amenazas, tantas constituciones dadas conforme a la religión por el César Carlos, y los príncipes que le precedieron no han contribuido en nada a evitar que tantos miles de hombres inocentes fueran exterminados por la espada, el hambre y las calamidades de una guerra inhumana y fuesen devastadas criminalmente extensísimas regiones de cultísimos y felicísimos reinos y provincias; [...] si de nada sirvieron los clamores de los hombres piadosos [...], ¿qué ocurrirá si esos malvados (a quienes, conforme al viejo proverbio, sólo les falta la ocasión) leyesen que un varón docto, Doctor en teología e historiador de la Corte, probaba en sus libros editados que aquellas guerras criminales y expediciones tártareas se confirmaban con los argumentos por él aducidos [...]. ¿A quién perdonarán? ¿Qué sangre no derramarán? ¿Qué sevicia no llevarán a cabo? $\gg^{60}$. Hemos de comprobar que Las Casas reconoce, en primer lugar, la labor legislativa humanitaria de la Corte y la existencia de españoles piadosos que clamaban contra las injusticias cometidas en ultramar. Pero, si toda esa labor había sido bienintencionada aunque bastante impotente a la hora de

\footnotetext{
59 Álvarez Uría, 2015: 219.

60 Sepúlveda y Casas, 1975: 116.
} 
mitigar (y no digamos ya detener) los crímenes de la colonización, qué no sucedería si tales atrocidades quedaban teológicamente amparadas, sancionadas y justificadas en un docto tratado. Por ello removió todo lo que estaba a su alcance para impedir su publicación, porque sabía que Sepúlveda no era una cabeza cualquiera. Y obtuvo éxito; finalmente, las Universidades de Alcalá y Salamanca dictaminaron que el tratado no era apto para ser impreso.

Esto, claro está, enfureció a Sepúlveda, que intentó conseguir la autorización entrando en franca disputa con figuras de la talla de Melchor Cano. Pero el tratado no fue impreso ni en España ni en América (este libro, de hecho, y a pesar de haber sido la causa inmediata de la disputa de Valladolid, no llegó a imprimirse hasta 1892). Entonces compuso la Apologia pro libro de justis belli causis, impreso en Roma en 1550, y a su vez escribió al príncipe Felipe para prevenirle de las doctrinas y maquinaciones del obispo de Chiapas. Todo lo cual desembocó, como decíamos, en el evento más importante y decisivo de toda la amplia discusión, que ya duraba lustros, generada en torno el problema de las Indias. Hablamos de la famosa disputa de Valladolid celebrada en 1550 y 1551. Recordemos que Francisco de Vitoria había muerto en 1546. Bien es verdad que ésta no fue la primera Disputa, pero sin duda resultó ser la más paradigmática. Y tengamos en cuenta la trascendencia política y económica de esta contienda, pues en aquellos tiempos el oro y la plata ya fluían masivamente hacia la península ibérica desde Potosí y Popayán. El pensamiento y el poder se hallaban íntimamente vinculados y todos los asuntos doctrinales devenían, en última instancia, cuestiones de estado.

Sepúlveda, que jamás puso un pie en América, se basaba principalmente en las apreciaciones de Gonzalo Fernández de Oviedo ${ }^{61}$. En su monumental Historia general y natural de las Indias, aparecida en 1535, y que tanta autoridad ejercería sobre Sepúlveda y otros muchos, desplegaba toda una serie de profusos argumentos y ejemplos con los que trataba de establecer la brutalidad congénita de los indios y su incorregible depravación, justificando su natural posición inferior con respecto a los españoles, los cuales tenían pleno derecho a ejercer su dominio imperial por los medios que fuere, incluidos los violentos $^{62}$. Pero Las Casas, fiero antagonista de Oviedo, al cual consideró poco menos que un «enemigo mortal del género humano», replicará durante toda su vida que el concepto mismo de «esclavitud natural» era absurdo, incluso impío63. Sepúlveda ya había publicado en 1535 Democrates primus, donde sostenía la perfecta conformidad del expansionismo militar del Empe-

\footnotetext{
61 Salas, 1959: 117-134.

62 Fernández de Oviedo, 1851-1855.

63 Salas, 1959: 287-294.
} 
rador con los principios cristianos. Algunos años antes, y en esa misma línea, había compuesto una Exhortación a la guerra contra el turco. La cristiandad, en todo el Mediterráneo, debía ser justamente defendida con la espada, haciendo frente al enemigo musulmán.

Sepúlveda, de una profunda cultura humanística (había traducido al latín la Política de Aristóteles), ejerció notable influencia, y rápidamente captó la atención de los defensores de las «guerras justas» contra los nativos americanos. En el mencionado Democrates Alter o Secundus, escrito por sugerencia, entre otros, del conquistador Cortés (por entonces retirado en Madrid), invocaba la autoridad de Aristóteles para justificar las prácticas esclavizadoras en América, como ya había hecho el dominico escocés John Major, que en un tratado de 1510 había sentenciado que la conquista violenta debía entenderse poco menos que como un deber civilizatorio, toda vez que aquellos pueblos bárbaros eran naturalmente siervos. El mero hecho de que aquellos bárbaros incultos viviesen bajo alguna forma de gobierno no probaba nada, simplemente que sobresalían levemente por encima de la condición animalesca. Sepúlveda hablaba con desprecio de «esos hombrecillos en los que apenas se pueden encontrar restos de humanidad ${ }^{64}$. En esta frase quedan condensados todos los motivos de su exposición. Para justificar su tesis añade que apenas pueden hallarse en sus rudos modos de vida rasgos de alta cultura o signos de verdadera civilización; los describe como cobardes, violentos y practicantes de horripilantes costumbres idólatras. No reinaba una paz idílica en aquellos lares antes de la llegada de los españoles, por cierto, sino cruentas y permanentes beligerancias intestinas. Fueron los españoles con su moral, sus letras y sus leyes quienes pudieron elevar a muchos de esos bárbaros impíos a la condición de verdaderos hombres. «¿Puede darse mayor o más claro testimonio de la ventaja que unos hombres tienen sobre otros en ingenio, habilidad, fortaleza de ánimo y virtud? ¿No es prueba de que ellos son siervos por naturaleza?» ${ }^{65}$. Y, apostilla, que algunos de ellos muestren cierto ingenio para ejecutar primorosamente algunas obras de artificio no evidencia que habite en ellos una humanidad equivalente a la nuestra, pues también las abejas y las arañas son capaces de habilidades semejantes. Tan alejados de toda virtud humana, era muy justo que aquellas bestias fueran dominadas por los prudentes y piadosos. «Así, pues, ¿dudaremos en afirmar que estas gentes tan incultas, tan bárbaras, contaminadas con tan nefandos sacrificios e impías religiones, han sido conquistadas por Rey tan excelente, piadoso y justo como fue Fernando y lo es ahora el César Carlos, y por una nación excelente en

\footnotetext{
64 Sepúlveda, 1984: 35.

65 Ibidem: 36.
} 
todo género de virtudes, con el mejor derecho y mayor beneficio para los propios bárbaros?» ${ }^{66}$. Y la respuesta a esa pregunta de Sepúlveda tuvo que ser afirmativa, toda vez que muchas e insignes cabezas dudaron y pusieron en entredicho toda esa batería de argumentos y razonamientos.

La inmortal disputa con Las Casas se celebró en el Colegio de San Gregorio de Valladolid, en Agosto y Septiembre de ese mismo año, 1550. Fue el propio emperador, como bien sabemos, quien mandó conformar una junta de letrados, teólogos y juristas para dirimir tan cruciales cuestiones. El primero que habló en la sesión de apertura fue Sepúlveda, y allí apelaría a versículos del Deuteronomio y de otros libros bíblicos para justificar el empleo violento de la espada para someter a cualquier tipo de infiel ${ }^{67}$. Basándose en la Historia General de Oviedo, justificará que los bárbaros son reducidos al dominio de los cristianos con todo derecho. "Ahora bien, tales gentes, por Derecho natural, deben obedecer a las personas más humanas, más prudentes y más excelentes para ser gobernadas con mejores costumbres e instituciones; si, previa la admonición, rechazan tal autoridad, pueden ser obligadas a aceptarla por las armas» ${ }^{68}$. Y una tal guerra siempre será justa, concluye. En su Apología, apelando al testimonio de las Sagradas Escrituras y a los textos de los conspicuos Doctores, Sepúlveda infiere que a estos bárbaros bien podría quitárseles sus tierras, sus bienes y hasta la vida como justo castigo, debido a sus prácticas idolátricas en las que eran inmolados cientos de inocentes ${ }^{69}$. Con pleno derecho, por violar toda ley natural y blasfemar contra Dios, pueden ser estos infieles bestiales sometidos al dominio espiritual y político de los cristianos.

Podemos descubrir en el alegato de Sepúlveda un razonamiento que preconiza la necesidad de una violencia permanente. «Si hay, pues, que emplear la fuerza, hay que utilizar la más útil, la que sirva para obligarlos a aceptar el imperio de los cristianos. Aparte de que, aunque los bárbaros llevados del miedo admitiesen a los predicadores y abandonasen por un tiempo su idolatría o más bien disimulasen abandonarla, no hay duda de que, una vez retirada la causa de su temor, volverían a sus primitivas costumbres y expulsarían a los predicadores y los matarían a ellos y a los por ellos convertidos si no volvían a su anterior impiedad [...]. Todas estas incomodidades y dificultades se eliminan fácilmente con la conquista de los bárbaros $\gg{ }^{70}$. El camino de la mera

\footnotetext{
66 Ibidem: 38.

67 Sepúlveda y Casas, 1975: 62.

68 Ibidem: 61.

69 Ibidem: 64.

70 Ibidem: 72.
} 
predicación doctrinal es arduo, lento y peligroso; por el contrario, el camino de la conquista violenta es rápido y eficaz. Y a Sepúlveda no le cabe la menor duda de que se ha de elegir la vía expedita de la violencia y el terror a la hora de afianzar y desarrollar el dominio cristiano de las Indias americanas. No sólo hay que amonestar a los bárbaros con palabras, hay que aterrorizarlos con un ejército. Y el motivo del terror, además, debe permanecer para ellos siempre visible. Refutando estos argumentos de Sepúlveda, Las Casas entendía que los naturales americanos no podían quedar incluidos dentro de la categoría de los siervos por naturaleza. De hecho, en su Apología no tendrá empacho en denominarlos «hermanos», con todo lo que semejante apelativo implica a nivel antropológico, moral, teológico y político. «¿Quién hay tan impío que quiera incitar a hombres crueles, ambiciosos, soberbios, avaros, desenfrenados y siempre ociosos, a robar a sus hermanos y a destruir sus almas al mismo tiempo que sus cosas, no siendo nunca lícita la guerra, sino solamente cuando se hace por inevitable necesidad? $\gg^{71}$. Resultaba abominable tratar de justificar todas las mortíferas guerras de conquista apelando a las sagradas escrituras, como hacía Sepúlveda ${ }^{72}$.

Pensaba Las Casas que la guerra contra los infieles de la tercera categoría (a saber, aquéllos que jamás han tenido conocimiento de la fe cristiana ni han cometido agravio alguno contra ella) es absolutamente tiránica e injusta en todos los supuestos. Según el criterio del cardenal Tomás Cayetano, que tuvo notable influencia en los dominicos españoles, los naturales americanos no podían ser considerados infieles en el mismo sentido en el que lo podrían ser otras gentes que sí habían conocido la fe cristiana y habían peleado contra ella. El dominico italiano, en sus Comentarios a la Secunda Secundae de 1517, estableció la mencionada distinción. En función de todo ello, Las Casas entiende que nadie debe ser «forzado a abrazar la fe», por muy bárbaros que a nosotros nos pudieran parecer los pueblos encontrados ${ }^{73}$. Pero, y Las Casas insiste mucho en esto, los presuntos bárbaros viven en realidad en grandes ciudades y dentro de complejos sistemas políticos y jurídicos, siendo muy capaces de gobernarse a sí mismos y sin necesidad alguna de vivir tutelados por otros ${ }^{74}$.

En su Defensa en contra de los perseguidores y calumniadores de las gentes del Nuevo Mundo descubierto del otro lado del mar, expuesta por Las Casas en la junta de Valladolid de 1550, insistía con vehemencia en la nece-

\footnotetext{
71 Ibidem: 122.

72 Ibidem: 121.

73 Ibidem: 137.

74 Ibidem: 134.
} 
sidad de no caer en la tentación de menospreciar las artes prácticas de aquellos pueblos, pues éstas denotan cualquier cosa menos una inteligencia raquítica o bestial. Un aspecto que, por cierto, ni siquiera a Hernán Cortés paso desapercibido ${ }^{75}$. Pero, y aquí llegamos al núcleo del asunto, consigna Las Casas que aquellas gentes no son un tumulto de bárbaros irracionales incapaces por naturaleza de establecer una forma ordenada de gobierno; muy al contrario, y como él mismo había podido comprobar, los indios americanos eran perfectamente capaces de autogobernarse con criterio y saludable rectitud. Tanto en la Apologética Historia, basada en sus propias experiencias, como en la inmortal querella de Valladolid, Las Casas dedicó cientos de párrafos a refutar la extendida noción de que los indios eran tan bestiales e inferiores que los españoles tenían derecho a ejercer una labor civilizadora por medios violentos, si fuera menester. En esencia quería mostrar, a través de numerosas descripciones de la vida de los pueblos americanos, el supremo error de considerar a los indios poco menos que animales irracionales incapaces de consumar una vida buena, ordenada e inteligente ${ }^{76}$.

Pero es más; pues, si acaso se diese la situación de que aquellos pueblos fuesen efectivamente inferiores a los españoles y a los cristianos en algunos aspectos, ijustificaría eso una «labor civilizadora» a sangre y fuego? Evidentemente no. «¿Soportaríais tú, Sepúlveda, que Santiago evangelizase a tus cordobeses de tal modo? [...]. ¿En esto consiste arrancar la fiera barbarie de las almas de los bárbaros o más bien esto es obrar como ladrones, asesinos y crueles salteadores y precipitar a aquellas mansísimas gentes en la desesperación? $\gg\rangle^{77}$. Pero Las Casas va mucho más lejos, toda vez que plantea la legítima defensa violenta ejercida por los pueblos cruelmente colonizados. «Por lo tanto, todo pueblo, por muy bárbaro que sea, puede defenderse de los ataques de otro pueblo superior en cultura que pretenda subyugarlo o privarle de libertad; es más, lícitamente puede castigar con la muerte a las personas de dicho pueblo superior en cultura como quienes criminal y violentamente le infieren una injusticia contra la Ley natural. Y tal guerra en verdad es más justa que aquélla que bajo pretexto de cultura se le hace» ${ }^{78}$. La guerra «legítima» va en esta ocasión en la otra dirección. Resulta verdaderamente sorprendente que una tesis de tal envergadura pudiera defenderse públicamente en el corazón mismo de la Corte imperial.

75 Hanke, 1985: 101.

76 Casas, 1958.

77 Sepúlveda y Casas, 1975: 135.

78 Ibidem: 138. 
Ya pudimos ver que otros destacados pensadores españoles, como Bartolomé Carranza o Diego Covarrubias, en los años anteriores al conflicto de Valladolid, enseñaban y escribían tesis contrarias a las de Sepúlveda. También el franciscano Jacobo de Testera, desde la Nueva España, se empeñó en defender con ardor las plenas capacidades culturales y espirituales de las poblaciones indígenas; envió una misiva con tales inquietudes al emperador Carlos $\mathrm{V}$, en 1533. El virrey Antonio de Mendoza, que había ofrecido todo su apoyo al obispo Zumárraga y a otros franciscanos cuando éstos edificaron una escuela para indios, pudo comprobar in situ el escaso fundamento de aquellas teorías que se empeñaban en sostener una supuesta incapacidad de los indios para el aprendizaje ${ }^{79}$. En la promulgación de la celebérrima bula Sublimis Deus del papa Paulo III, en 1537, jugó un papel determinante la intervención de los dominicos Bernardino de Minaya y Julián Garcés. Minaya, interrumpiendo sus labores misioneras en América, había regresado en 1535 con el objetivo expreso de defender la cusa de los indios. Desde España viajó a Roma para demostrar ante Paulo III la falsedad de aquella tesis que consideraba a los indios bruta animalia. Garcés, obispo de Tlaxcala en la Nueva España, envió a Roma un largo alegato en los mismos términos que los empleados por Minaya. Aquella bula papal, que condenaría la esclavización y el despojo de los indios, resultó ser un arma dialéctica a la que Las Casas habría de recurrir, siquiera de manera velada, a lo largo de sus disputas. La difusión sin permiso en América de Sublimis Deus le costó a Minaya dos años de prisión. Poco después, en 1538, y a instancias de Carlos V (que había interpretado tal bula como una intervención excesiva del Sumo Pontífice en su maquinaria política imperial), el Papa revocaba la bula. Pero, a pesar de todo, la discusión acerca de la naturaleza de los indios y la subsecuente legitimidad de la Conquista habrían de seguir ventilándose, incluso bajo el auspicio del propio Carlos V, en la América Hispana y en la península ibérica.

Es verdad que la disputa no detuvo la marcha de la conquista hacia nuevos territorios, ni los abusos desaparecieron. Pero Las Casas continuó presentando memoriales e informes al rey y al Consejo de Indias, y las tesis de Sepúlveda jamás pudieron imponerse. Estos acontecimientos habían de entenderse, como bien señaló Lewis Hanke, como «el testimonio apasionado de un hecho decisivo en la historia de la humanidad $»^{80}$. Aquel hito conllevó la germinación de una idea imperecedera, a saber, que todos los pueblos del mundo forman parte de un mismo género humano. En 1563, tres años antes de su muerte en el convento dominico de Atocha, Las Casas compuso en Sevilla, sin el con-

\footnotetext{
79 Hanke, 1985: 58.

80 Hanke, 1988: 377.
} 
sentimiento del Consejo de Indias, De imperatoria seu regia potestate, quizás el texto más radical y avanzado de todos. Publicado póstumamente en Fráncfort, en 1571, contiene la versión más acabada de las tesis lascasianas. Allí sostendrá sin vacilación que la servidumbre es un fenómeno absolutamente «accidental», esto es, que dicha servidumbre jamás pertenece a la «esencia» de nadie. La esclavitud, en suma, jamás tiene causas naturales. «Desde el principio del género humano, todos los hombres, todas las tierras y todas las otras cosas, por derecho natural y de gentes, fueron libres y alodiales, o sea francas y no sujetas a servidumbre [...]. En cuanto al hombre se demuestra, porque desde el origen de la naturaleza racional todos los seres humanos nacían libres. Puesto que siendo todos los hombres de igual naturaleza, no hizo Dios a un hombre siervo, sino que a todos concedió idéntica libertad» ${ }^{81}$. Es verdad que, en ese avance hacia el reconocimiento del género humano, los tratados florentinos sobre la dignidad del hombre ocuparon un lugar muy relevante. Cómo no pensar, de igual modo, en la Universidad de Padua. Pero es el encuentro con América y el conocimiento de sus habitantes lo que produce la ruptura epistemológica que obligó a repensar todos los elementos que componían la visión del mundo dominante. Y la modernidad jurídica alcanzada en los pasajes de los teólogos españoles no tenía parangón ${ }^{82}$.

Domingo de Santo Tomás, otro dominico, gran admirador y amigo de Las Casas, proseguiría su lucha a favor de los indios en unos términos igualmente radicales, toda vez que la condición de aquellas gentes bajo el yugo español «es aún peor que la del asno en Castilla» ${ }^{83}$. Estudió la lengua de los indios peruanos, y publicó una gramática con el ánimo expreso de derrumbar la tesis de su incapacidad congénita. Alonso de la Vera Cruz, que había sido discípulo de Vitoria, igualmente tomaría el testigo de las enseñanzas de Las Casas $^{84}$. También resonó su voz en los obispos Miguel de Benavides y Domingo de Salazar, que se opusieron a la colonización sangrienta de Filipinas.

Cuando Francisco de Toledo, virrey del Perú, llegó a Lima en 1569 entendió que los escritos de Las Casas, que había muerto en 1566 (llevaba más de veinte años sin viajar a América) perturbaban notablemente el devenir del imperio español. Toledo intentó requisar todos sus escritos e impedir que llegaran más desde la metrópoli; tal era la influencia, como una onda expansiva que sacudió todos los rincones del imperio hispánico, del pensamiento

\footnotetext{
81 Casas, 1969: 16.

82 Dell'no Maini, 1951.

83 Hanke, 1985: 159.

84 Torre Rangel, 1998.
} 
de aquel irreverente fraile ${ }^{85}$. Fray Toribio de Benavente (que adoptó el apodo o sobrenombre de «Motolinía»), misionero franciscano e historiador de la Nueva España, acusó a Las Casas de ser un hiperbólico idealista que perturbaba el buen orden colonial, y lo denunció en una carta enviada a Carlos V en 1555. El extremismo lascasiano, su rigorismo desmedido, llevaba a conclusiones inadmisibles, tales como que «todo» bien que detentan los españoles en las Indias ha sido «mal adquirido» ${ }^{86}$. Las Casas, a su vez, denunció al franciscano ante el emperador Carlos, por ser un fomentador de los abusos hispanos en tierras americanas. Es verdad que la célebre Brevísima relación de la destrucción de las Indias, aparecida en 1552, fue traducida en múltiples ocasiones a las principales lenguas europeas; y es también es cierto que fue utilizada por muchos filósofos del siglo XVIII para construir un relato absolutamente ignominioso e inhumano de la Conquista española, impugnada en su totalidad ${ }^{87}$. Aunque, sin duda, el ataque más virulento contra el fraile dominico fue trabado por Ramón Menéndez Pidal. Éste, haciendo hincapié en las exageraciones estadísticas de Las Casas, no ahorró adjetivos peyorativos a la hora de juzgar la vida y obra del obispo de Chiapas. Pero, más allá de los ataques ad hominem (de corte psicopatológicos) que lanzó contra el fraile sevillano, la tesis interesante de Menéndez Pidal es aquélla que insinúa que la utilización de la obra lascasiana por parte de los seculares enemigos del Imperio español fue muy importante en la progresiva derrota de éste; aquella obra, sostiene, también sería decisiva a la hora de proveer material ideológico en el inicio de los procesos de independencia de las colonias hispanoamericanas $^{88}$. El historiador español Américo Castro incidió en tesis muy similares y, de igual modo, subrayó que llevado por su entusiasmo relativista llegó a escribir en el capítulo CXXX de su Apologética historia que, desde lo alto de los templos aztecas, lugar de multitudinarios festines de antropofagia ritual, todo resulta «alegre y admirable» ${ }^{89}$.

Es verdad que, en un momento dado, Las Casas llegó a postular que los negros debían ser llevados a las colonias para suplir el trabajo embrutecedor llevado a cabo por los indios. Lo hizo, por ejemplo, en una misiva al Consejo de Indias redactada en 1531. Pero cuando tomó conciencia de las prácticas inhumanas llevadas a cabo con la población africana, se retractó contundentemente de su anterior opinión y entonó un mea culpa sin paliativos, toda vez

85 Hanke, 1988: 429.

86 Bataillon, 2013: 68-75.

87 Hanke, 1988: 391.

88 Menéndez Pidal, 1963: 360-375.

89 Castro, 2002. 
que «ser tan injusto el captiverio de los negros como el de los indios» $\rangle^{90}$. Sus críticas a la esclavización de los negros son minúsculas, en comparación con su inmensa apología indiana. Pero no dejó de hacerlas. Como afirmara Bataillon, Las Casas fue uno de los primeros en tomar conciencia del problema moral y de derecho que planteaba el tráfico de negros ${ }^{91}$. Y, en ese sentido, resulta insustentable la ominosa leyenda que en torno a semejante cuestión gravitó sobre su figura ${ }^{92}$. El origen de ese equívoco podría residir en el hecho de que sus manifestaciones más vehementes contra la esclavitud de los africanos, contenidas en Historia de las Indias, permanecieron inéditas hasta la segunda mitad del siglo XIX.

Fue terrible y cruenta la historia de la esclavización de los negros ${ }^{93}$. Ya a finales del siglo XVII un aragonés perteneciente a la Orden de los Capuchinos, Francisco José de Jaca, mantuvo tesis radicalmente abolicionistas. Junto a Epifanio de Moirans, compañero de orden, luchas y fatigas, predicó incansablemente que los negros eran libres por derecho, que su traslado y retención como esclavos era un acto del todo injusto y que los poseedores de esclavos estaban obligados a restituirles la libertad y a compensarles por su ilícito cautiverio. Con ello, escandalizaron a los estamentos más poderosos de la sociedad colonial y se enfrentaron a las autoridades civiles y eclesiales. Pero en La Habana y en otros lugares mantuvieron en todo momento que se esclaviza contra el derecho natural, que no hay guerra justa que legitime el mercadeo de hombres negros capturados en su tierra natal a través de trapacerías y violencias. Porque los negros, y esto es fundamental, no solamente en cuanto cristianos son libres, sino también en su estado originario.

Por supuesto, semejantes pensamientos le acarrearon a Francisco José de Jaca, y también a Moirans, severas amonestaciones, la suspensión de sus facultades ministeriales, su prendimiento y finalmente la obligación de regresar a España. Su asunto llegó a ser considerado por el Consejo de Indias y el Consejo de Estado, tal era la trascendencia del revuelo causado en La Habana por estos dos beligerantes capuchinos. Pero, en cualquier caso, su Resolución sobre la libertad de los negros, aparecida en 1682 (aunque terminada ya en 1681), permanecerá como un hito de la libertad por ser, precisamente, la primera condena sistemática de la esclavitud del pueblo negro elaborada por el pensamiento hispano y, quizás, por el pensamiento universal ${ }^{94}$. Unas tesis

\footnotetext{
90 Casas, 1981: 275.

91 Bataillon, 1976: 136.

92 Ortiz, 1952: 146-184.

93 Deive, 1980.

94 Jaca, 2002.
} 
que cuestionaban los fundamentos mismos de toda la estructura socioeconómica del mundo colonial ibérico.

Cabe hablar, incluso, de una vertiente republicana en el pensamiento hispano del siglo XVI. Destaca en ese sentido el jurista vallisoletano Vázquez de Menchaca, infinitamente menos conocido que otros hombres de su siglo, pero cuyas tesis fueron en algunos aspectos mucho más audazmente democratizadoras. Sostenía sin ambages que el Príncipe, cuyo poder jamás podía estar fundamentado en Dios, encontraba su legitimidad sólo en la comunidad política popular. «En efecto, el principio supremo que preside la doctrina de Vázquez sobre el origen, naturaleza, contenido y límites del poder político es el que se expresa bajo el aforismo Principatus legitimus ex solo populi consensu» ${ }^{95}$ Afirmaba tajantemente la sumisión del poder al Derecho, por lo cual el monarca jamás podía encarnar una potencia absoluta. La voluntad del monarca no era fuerza de ley, pues el imperio de las leyes también doblega su magna voluntad. Digamos de pasada que en el tema de la propiedad privada, que era caracterizada como un derecho de gentes "secundario», cabía la posibilidad de una expropiación forzosa si ello se justificaba por consideraciones de utilidad pública. El republicanismo incipiente era notable en esa tesis, puesto que ningún poder privado vinculado a la riqueza debería estar por encima del orden de las leyes ${ }^{96}$. En sus Controversias ilustres Vázquez de Menchaca dejaba meridianamente claro que el príncipe está sujeto a las leyes del derecho natural, pero también a las leyes positivas y civiles de la república ${ }^{97}$. El jurista español, a mediados del siglo XVI, establecía que sólo en el consentimiento de los ciudadanos se hallaba la razón de ser de los que gobiernan, y éstos sólo podían justificar su ejercicio en el gobierno con la persecución del bien de aquellos ciudadanos. Y, por supuesto, en su pensamiento quedaba contemplada la resistencia activa contra el magistrado cuando éste fuese autor de violencia y tiranía.

Es verdad que la modernidad hispana del siglo XVI quedó truncada. El imperio español, ya en los últimos lustros del XVI y sobre todo en el XVII, empezó a cerrarse sobre sí mismo. La cruenta intolerancia contrarreformista cobró tintes dramáticos, se persiguió crudamente el pensamiento libre, retornó la feroz lógica de fieles e infieles y la Inquisición funcionó a toda máquina. La detención y el subsiguiente proceso contra Bartolomé Carranza, llevado a cabo por el Gran Inquisidor Fernando de Valdés, resultó ser todo un símbolo de la decadencia de la Escuela de Salamanca y de las ideas que de ésta habían

\footnotetext{
95 Carpintero Benítez, 1977: 132.

96 Ibidem: 154.

97 Ibidem: 161.
} 
brotado $^{98}$. Todo aquello que los teólogos dominicos del siglo XVI habían empezado a movilizar, al calor de la tremenda cuestión indiana, quedó bloqueado. Pero su huella en la historia sería ya indeleble.

\section{UNA MODERNIDAD DEL SUR}

La tesis que caracteriza la modernidad europea (y, por extensión imperial, americana) como un fenómeno histórico-espiritual de raíces eminentemente protestantes, cronológicamente iniciado y desplegado en los siglos XVII y XVIII, ha sido hegemónica ${ }^{99}$. Pero, en realidad, hemos de acudir al mundo sureño, mediterráneo y católico, para encontrar el origen de muchos de aquellos elementos de lo que luego habría de ser la vertiente más humana de la modernidad. "A mi juicio el protestantismo no liberó a las sociedades occidentales del medievalismo católico. Me parece que apelando a materiales históricos se puede cuestionar que el protestantismo haya engendrado el mundo moderno. Sin duda el pietismo protestante está en la base del "espíritu del capitalismo", pero es preciso distinguir el capitalismo de la modernidad, a la vez que tener en cuenta que el protestantismo nació como un fundamentalismo religioso, un fideísmo irracional, que hacía inviable el paso de la centralidad de Dios a la centralidad de los seres humanos» ${ }^{100}$. De iure belli ac pacis, aparecida en 1625 y escrita en latín por el holandés Hugo Grocio, ha sido considerada con razón una obra fundamental en el desarrollo del moderno derecho internacional ${ }^{101}$. Pero es muy importante notar que el contenido de esta obra debe muchísimo a los teólogos españoles del siglo anterior. En los riquísimos y acalorados debates teológico-morales, jurídicos y políticos que tuvieron lugar en el siglo XVI dentro de las Universidades de Salamanca, Évora o Coímbra podemos hallar las raíces vigorosas de un proceso modernizador que, ulteriormente, hubo de quedar truncado en España. "A mi juicio fue el descubrimiento del "género humano" en el siglo XVI, en el marco del mundo católico, el detonante que hizo posible pasar de la dignidad del hombre de los humanistas, al derecho natural, y de éste a los derechos humanos emancipados ya de las creencias religiosas» ${ }^{102}$. Bien es verdad, no obstante, que ya a finales del siglo XVI,

\footnotetext{
98 Álvarez Uría, 2015: 265.

99 Habermas, 2008.

100 Álvarez Uría, 2015: 16.

101 Grocio, 1925.

102 Álvarez Uría, 2015: 17.
} 
y sobre todo a partir del 1600, esa libertad del espíritu crítico sufrió un más que considerable retroceso. Pero fue el pensamiento hispánico de la llamada «segunda escolástica», nucleado en torno a la Escuela de Salamanca, el que alumbró la novísima idea de una «humanidad común», en base a la cual hubo de tejerse la noción de un derecho de gentes de validez universal. Aquel pensamiento, evidentemente, no podía gestarse sino en el marco conceptual de la teorización teológica; pero, en cualquier caso, se transitaba ya hacia un horizonte de sentido que dejaba atrás algunas nociones centrales del pensamiento medieval.

Por el contrario, Ernst Troeltsch aseveró que la cultura católica fue «autoritaria en grado máximo» ${ }^{103}$, debido a lo cual se agitó dentro de la modernidad como un aparatoso "cuerpo extraño»" 104 . Es cierto que el pensador alemán consideraba que el viejo luteranismo, todavía anclado al mundo medieval, había permanecido igualmente sumergido en un fideísmo irracionalista que contemplaba el mundo desde lo sobrenatural y lo revelado. Postulaba, empero, que el protestantismo ulterior hubo de «cooperar considerablemente en la creación del mundo moderno» ${ }^{105}$. Pero cabría preguntarse, como venimos haciendo a lo largo de estas páginas, si el mundo católico en ningún momento y en modo alguno contribuyó a dicha creación. De hecho, es el propio Troeltsch quien tiene que admitir que el movimiento iusnaturalista con el que comienza la moderna formación del derecho no fue hijo del espíritu protestante de los siglos XVI y XVII ${ }^{106}$. En efecto, no podríamos atribuir a las diversas sectas protestantes que arraigaron y se extendieron por Norteamérica, como así lo pretendiera Georg Jellinek, lo que en verdad había quedado ya desarrollado por los teólogos españoles del siglo XVI ${ }^{107}$. Pero lo cierto es que aquellos teólogos no son mencionados en ningún momento por Jellinek o Troeltsch. Y es por ello que asumimos la tesis de Fernando Álvarez-Uría: «La modernidad del Sur, la modernidad de los países católicos, no debe por tanto quedar eclipsada, y por consiguiente desplazada, por la hegemónica modernidad del Norte, la modernidad protestante» ${ }^{108}$. También Richard M. Morse entendió que no eran lo mismo «Iberoamérica» y «Angloamérica» y, remontándose a la prehistoria de la modernidad para evaluar mejor sus líneas de fuerza y sus contrastes, com-

\footnotetext{
103 Troeltsch, 1983: 14.

104 Ibidem: 17.

105 Ibidem: 27.

106 Ibidem: 58.

107 Jellinek, 1984: 97.

108 Álvarez Uría, 2015: 24.
} 
prendió que hubo una modernidad latina que en absoluto debía ser menospreciada $^{109}$.

La cultura jurídica del derecho natural no halla sus genuinas raíces en el mundo protestante, como hemos podido comprobar a lo largo de este trabajo. Fue en la Europa de sur donde se abrió paso la noción misma de «género humano», y con ello se echaron los cimientos más remotos de la modernidad. «La nueva noción de "humanidad" no irrumpió de repente en la escena social, ni tampoco surgió por generación espontánea ${ }^{110}$. Pero es verdad que su maduración y su eclosión, su salida a la luz, tuvo lugar en el marco de la Escuela de Salamanca. Y desde allí el nuevo pensamiento irradiaría hacia Hispanoamérica y, sólo posteriormente, alcanzaría tierras holandesas. «Los efectos sociopolíticos e intelectuales que se derivaron de las categorías de pensamiento sobre las que se articuló este colegio de pensamiento aún no han sido a mi juicio suficientemente reconocidos por los historiadores del mundo moderno, ni tampoco han encontrado el espacio que se merecen en los manuales de historia de las ideas sociales y políticas» ${ }^{111}$. Este trabajo ha querido, desde su humildad, contrarrestar esa deficiencia.

\section{BIBLIOGRAFÍA}

Álvarez Uría, Fernando, El reconocimiento de la humanidad. España, Portugal y América Latina en la génesis de la modernidad, Madrid, Morata, 2015.

Ardiles, Osvaldo et al., Hacia una filosofía de la liberación latinoamericana, Buenos Aires, Bonum, 1973.

Bataillon, Marcel, Estudios sobre Bartolomé de Las Casas, Barcelona, Península, 1976.

Bataillon, Marcel, Las Casas en la historia, México, Fondo de Cultura Económica, 2013.

Beltrán de Heredia, Vicente, "Personalidad del maestro Francisco de Vitoria y transcendencia de su obra doctrinal", F. de Vitoria, Relectio de Indis o libertad de los indios, Madrid, CSIC, 1967: XIII-XXIX.

Brufau Prats, Jaime, "La aportación de Domingo de Soto a la doctrina de los derechos del hombre y las posiciones de Bartolomé de Las Casas", La Escuela de Sala-

109 Morse, 1999.

110 Álvarez Uría, 2015: 19.

111 Idem. 
manca ante el descubrimiento del Nuevo Mundo, Salamanca, San Esteban, 1988: 103-119.

Bueno, Gustavo, España frente a Europa, Barcelona, Alba, 1999.

Carpintero Benítez, Francisco, Del derecho natural medieval al derecho natural moderno: Fernando Vázquez de Menchaca, Salamanca, Universidad de Salamanca, 1977.

Carranza, Bartolomé de, “¿Por razón de fe puede el Cesar hacer la guerra y retener a los indios del Nuevo Orbe?", Luciano Pereña (introd. y comp.), Misión de España en América, 1540-1560, Madrid, CSIC, 1956: 38-57.

Casas, Bartolomé de las, Apologética historia. Obras escogidas de Fray Bartolomé de las Casas. Vol. 4, Madrid, Atlas, 1958.

Casas, Bartolomé de las, De regia potestate o derecho de autodeterminación, Madrid, CSIC, 1969.

Casas, Bartolomé de las, Del único modo de atraer a todos los pueblos a la verdadera religión, México, Fondo de Cultura Económica, 1975.

Casas, Bartolomé de las, Historia de las Indias. III, México, Fondo de Cultura Económica, 1981.

Casas, Bartolomé de las, Brevísima relación de la destrucción de las Indias, Madrid, Cátedra, 1982.

Castro, Américo, "Fray Bartolomé de Las Casas", Cervantes y los casticismos españoles, Madrid, Trotta, 2002: 223-303.

Covarrubias y Leyva, Diego, "Justicia de la guerra contra los indios", Luciano Pereña (introd. y comp.), Misión de España en América, 1540-1560, Madrid, CSIC, 1956: 184-231.

Covarrubias y Leyva, Diego, Textos jurídico-políticos, Madrid, Instituto de Estudios Políticos, 1957.

Deive, Carlos Esteban, La esclavitud del negro en Santo Domingo (1492-1844), Santo Domingo, Museo del Hombre Dominicano, 1980.

Dell'no Maini, Atilio et al., La conquista de América y el descubrimiento del moderno Derecho Internacional. Estudios sobre las ideas de Francisco de Vitoria, Buenos Aires, Kraft, 1951.

Dumont, Jean, El amanecer de los derechos del hombre. La Controversia de Valladolid, Madrid, Encuentro, 2009.

Dussel, Enrique, Filosofía de la liberación, Buenos Aires, La Aurora, 1985.

Dussel, Enrique, "Más allá del eurocentrismo: el sistema-mundo y los límites de la Modernidad", Santiago Castro-Gómez, Óscar Guardiola-Rivera y Carmen Millán 
de Benavides (eds.), Pensar (en) los intersticios. Teoría y práctica de la crítica poscolonial, Bogotá, Instituto Pensar, Centro Editorial Javeriano, 1999: 147-161.

Fernández de Oviedo, Gonzalo, Historia general y natural de las Indias, Islas y Tierra Firme del mar océano, 4 vols., Amador de los Ríos (ed.), Madrid, Real Academia de la Historia, 1851-1855.

Friede, Juan, Vida y luchas de Don Juan del Valle, primer Obispo de Popayán y protector de indios, Popayán, Universidad Popayán, 1961.

Gómez de Gómara, Francisco, Historia general de las Indias, Madrid, Espasa-Calpe, 1941.

Grocio, Hugo, Del derecho de la guerra y de la paz, Madrid, Reus, 1925.

Habermas, Jürgen, El discurso filosófico de la modernidad, Madrid, Katz, 2008.

Hanke, Lewis, La humanidad es una. Estudio acerca de la querella que sobre la capacidad intelectual y religiosa de los indígenas americanos sostuvieron en 1550 Bartolomé de las Casas y Juan Ginés de Sepúlveda, México, Fondo de Cultura Económica, 1985.

Hanke, Lewis, La lucha por la justicia en la conquista de América, Madrid, Istmo, 1988.

Jaca, Francisco José de, Resolución sobre la libertad de los negros y sus originarios, en estado de paganos y después ya cristianos, Madrid, CSIC, 2002.

Jellinek, Georg, Orígenes de la declaración de derechos del hombre y del ciudadano, Madrid, Editora Nacional, 1984.

Kusch, Rodolfo, Esbozo de una antropología filosófica americana, Buenos Aires, Castañeda, 1978.

Lavallé, Bernard, Bartolomé de las Casas. Entre la espada y la cruz, Barcelona, Ariel, 2009.

Levene, Ricardo, Las Indias no eran colonias, Buenos Aires, Corregidor, 1991.

Losada, Ángel, Fray Bartolomé de Las Casas, a la luz de la moderna crítica histórica, Madrid, Tecnos, 1970.

Mariátegui, José Carlos, Ensayos escogidos, Lima, Patronato del Libro Peruano, 1956.

Marx, Karl y Engels, Friedrich, Materiales para la historia de América Latina, Córdoba, Argentina, Pasado y Presente, 1972.

Menéndez Pidal, Ramón, El Padre Las Casas: su doble personalidad, Madrid, Espasa-Calpe, 1963.

Mignolo, Walter, Historias locales, diseños globales. Colonialidad, conocimientos subalternos y pensamiento fronterizo, Madrid, Akal, 2003. 
Morse, Richard M., El espejo de Próspero. Un estudio de la dialéctica del Nuevo Mundo, México, Siglo XXI, 1999.

Ortiz, Fernando, "La leyenda negra contra fray Bartolomé de las Casas", Cuadernos americanos, 5 (México, 1952): 146-184.

Polo Blanco, Jorge, “Teoría de la dependencia y colonialidad del poder. Dos ángulos de una misma dominación", Revista San Gregorio, 11/1 (San Gregorio de Portoviejo, 2016): 6-17.

Poncela González, Ángel (ed.), La Escuela de Salamanca. Filosofía y humanismo ante el mundo moderno, Madrid, Verbum, 2015.

Quijano, Aníbal, "Colonialidad y Modernidad-Racionalidad”, Heraclio Bonilla (comp.), Los Conquistados. 1492 y la población indígena de las Américas, Quito, FLACSO/Ediciones Libri Mundi, 1992: 437-449.

Quijano, Aníbal, “Colonialidad del poder, cultura y conocimiento en América Latina”, Anuario Mariateguiano, 9/9 (Lima, 1997): 113-121.

Ramos, Demetrio et al., Francisco de Vitoria y la Escuela de Salamanca. La ética en la Conquista de América, Madrid, CSIC, 1984.

Rivera Cusicanqui, Silvia, Violencias (re) encubiertas en Bolivia, La Paz, Editorial Piedra Rota, 2010.

Rodó, José Enrique, Ariel, Madrid, Cátedra, 2007.

Rodríguez Molinero, Marcelino, "La doctrina colonial de Francisco de Vitoria, legado permanente de la Escuela de Salamanca", Anuario de filosofía del derecho, VIII (Madrid, 1991): 43-75.

Salas, Alberto M., Tres cronistas de Indias. Pedro Mártir de Anglería, Gonzalo Fernández de Oviedo, Fray Bartolomé de Las Casas, México, Fondo de Cultura Económica, 1959.

Salazar Bondy, Augusto, Dominación y liberación. Escritos 1966-1974, Lima, Universidad Nacional Mayor de San Marcos, 1995.

Scannone, Juan Carlos, Nuevo punto de partida en la filosofía latinoamericana, Buenos Aires, Guadalupe, 1990.

Sepúlveda, Juan Ginés de, Demócrates Segundo o de las justas causas de la guerra contra los indios, Madrid, CSIC, 1984.

Sepúlveda, Juan Ginés de y Casas, Bartolomé de las, Apología de Juan Ginés de Sepúlveda contra Fray Bartolomé de Las Casas y de Fray Bartolomé de Las Casas contra Juan Ginés de Sepúlveda, Madrid, Editora Nacional, 1975.

Serna, Mercedes (ed.), La conquista del Nuevo Mundo. Textos y documentos de la aventura americana, Madrid, Castalia, 2012. 
Serrano Gassent, Paz, Vasco de Quiroga. Utopía y derecho en la conquista de América, Madrid, UNED/Fondo de Cultura Económica, 2001.

Soto, Domingo, Relecciones y opúsculos I, Salamanca, Editorial San Esteban, 1995.

Stavenhagen, Rodolfo, Derecho indígena y derechos humanos en América Latina, México, Instituto Interamericano de Derechos Humanos/El Colegio de México, 1988.

Todorov, Tzvetan, La conquista de América. El problema del otro, México, Siglo XXI, 1987.

Torre Rangel, Jesús Antonio, Alonso de la Vera Cruz, amparo de los indios. Su teoría y práctica jurídica, México, Universidad Autónoma de Aguascalientes, 1998.

Troeltsch, Ernst, El protestantismo y el mundo moderno, México, Fondo de Cultura Económica, 1983.

Vasconcelos, José, La raza cósmica, México, Porrúa, 2001.

Vélez, Iván, Sobre la Leyenda Negra, Madrid, Encuentro, 2014.

Vitoria, Francisco de, Relecciones, México, Porrúa, 1985.

Wallerstein, Immanuel, Universalismo europeo. El discurso del poder, México, Siglo XXI, 2007.

Zavala, Silvio, La defensa de los derechos del hombre en América Latina (siglos XVI-XVIII), París, Unesco, 1963.

Zavala, Silvio, Las instituciones jurídicas en la conquista de América, México, Porrúa, 1971.

Zavala, Silvio, La filosofía política en la conquista de América, México, Fondo de Cultura Económica, 1984.

Zea, Leopoldo, Dependencia y liberación en la cultura latinoamericana, Tabasco, Mortiz, 1974.

Fecha de recepción: 10 de septiembre de 2015.

Fecha de aceptación: 23 de noviembre de 2015. 


\section{Asserting Southern modernity. The recognition of "human nature" in sixteenth-century Hispanic thought}

This study outlines a vindication of Hispanic thinking, which, in the heat of the Conquest of the Americas, produced a powerful body of innovative reflections that broke away from the epistemic and ideological moulds of medieval theocracy. Largely introduced by figures in the Dominican religious order, this thinking was constructed within scholastic theological moulds, but actually opened a fecund, and intellectually ground-breaking territory in terms of law, ethics and anthropological philosophy. Its theoretical contribution had an extraordinary scope that has not always been valued by historiography. This thinking, which was a primordial and primitive step in the germination of modernity, took place in a Southern, and a Catholic context. It is true that this incipient modernity was left buried and isolated as of the last quarter of the sixteenth century, particularly after 1600. The baton then passed to Northern protestant countries, such as Holland. We believe, however, that this Hispanic thinking should be recognized and studied, as it illuminated the seminal category of human nature, with all the associated implications, for the very first time.

KEY WORDS: Conquest of America; the School of Salamanca, human nature; Ius gentium. 